\title{
THE BLOOD AND SPINAL FLUID SUGAR AND CHLORIDE CONTENT IN MENINGITIS
}

\author{
BY \\ ESTHER HENDRY, M.B., Ch.B. \\ chemical Laboratory, Royal Hospital for Sick Children, Glasgow)
}

(From the Department of Paediatrics, Glasgow University, and the Bio-

It has long been recognized that the cerebrospinal fluid contains glucose and chlorides and that in meningitis their amount is reduced. This is generally supposed to be of diagnostic importance in distinguishing meningitis from certain other diseases in which there is a meningeal reaction, such as acute anterior poliomyelitis. In the present paper a study of the sugar and chloride content of the cerebrospinal fluid from children suffering from conditions other than meningitis (control series) and from cases of meningitis has been made, and the results correlated with the sugar and chloride content of the blood. The control series consisted of seventeen cases with no organic meningeal disease and from whom lumbar puncture, performed for diagnostic purposes, yielded a normal cerebrospinal fluid. Care was taken to exclude all cases in which there had been convulsions, as these have been proved to cause a marked alteration in the blood sugar content (MacLean, 1936). Of the meningitis cases there were twenty-eight with tuberculous meningitis, fourteen with meningococcal, one with pneumococcal, two with B. coli, two with influenzal and one with benign lymphocytic meningitis. All the cases had fasted for at least five hours before the blood and cerebrospinal fluid were taken. The blood was always obtained immediately before the lumbar puncture was performed as withdrawal of cerebrospinal fluid is known to cause a substantial rise in the blood sugar (Weichsel and Herzger, 1936).

Methods. - The blood and spinal fluid sugar was estimated by the modified Folin-Wu (1920) method on $0 \cdot 2$ c.c. of blood and 1 c.c. of cerebrospinal fluid. For chloride estimations, 1 c.c. of blood or cerebrospinal fluid was used under the conditions worked out by Whitehorn for performing the Volhard titration method (Van Slyke, 1924).

\section{The percentage of sugar in the cerebrospinal fluid}

Normal fluid.-From a review of the literature it appears that in normal subjects there are wide variations in the percentage of sugar in the cerebrospinal fluid. The findings obtained by various writers (table 1) show a wide range of normality, but the lowest finding is not less than $35 \mathrm{mgm}$. per cent. The results obtained in the present investigation are similar though the lowest 
limit is here $50 \mathrm{mgm}$. per cent. (table 2). Possibly the wide variations may be explained by concomitant variations in the blood sugar content. It is known that, even in normal circumstances, the blood sugar is subject to wide fluctuations ; thus excitement, pain or the ingestion of carbohydrate produce striking alterations and it seems reasonable to suppose that the cerebrospinal fluid sugar will show similar changes. If this is in fact the case, then, in spite of variations in the blood sugar content, the ratio of cerebrospinal fluid sugar to blood sugar should be constant. Table 3 gives the results arrived at by various workers. This shows a wide range and reference to table 2 shows an equally wide range in the cases investigated. The lowest ratio found by other workers is 0.42 while in the present series it is $0 \cdot 60$.

TABLE 1

THE CEREBROSPINAL FLUID SUGAR CONTENT IN NORMAL CASES

\begin{tabular}{|c|c|c|c|c|c|}
\hline \multicolumn{4}{|l|}{ OBSERVER } & \multicolumn{2}{|c|}{ C.S.F. SUGAR IN MGM. PER CENT. } \\
\hline & & & & MAXIMUM & MINIMUM \\
\hline $\begin{array}{l}\text { Wright, Herr and Paul (1931) } \\
\text { Cohn, Levinson and McCarth } \\
\text { Nissen (1937) } \\
\text { Rimele (1938) } \\
\text { Goodwin and Shelley (1925) } \\
\text { Hendry (present series) }\end{array}$ & $\begin{array}{l}1933) \\
\ldots \\
\cdots \\
\ldots\end{array}$ & $\begin{array}{l}\cdots \\
\cdots \\
\cdots \\
\cdots \\
\cdots\end{array}$ & $\begin{array}{l}\cdots \\
\cdots \\
\cdots \\
\cdots \\
\cdots\end{array}$ & $\begin{array}{l}80 \\
75 \\
65 \\
60 \\
77 \\
83\end{array}$ & $\begin{array}{l}45 \\
38 \\
35 \\
40 \\
40 \\
50\end{array}$ \\
\hline
\end{tabular}

TABLE 2

BLOOD AND CEREBROSPINAL FLUID SUGAR CONTENT IN CASES NOT SUFFERING FROM MENINGITIS (CONTROL SERIES)

\begin{tabular}{|c|c|c|c|c|}
\hline CASE & $\begin{array}{l}\text { BLOOD SUGAR } \\
\text { MGM. PER CENT. }\end{array}$ & $\begin{array}{c}\text { C.S.F. SUGAR } \\
\text { MGM. PER CENT. }\end{array}$ & $\begin{array}{l}\text { RATIO OF C.S.F. } \\
\text { TO BLOOD SUGAR }\end{array}$ & DIAGNOSIS \\
\hline $\begin{array}{r}1 \\
2 \\
3 \\
4 \\
5 \\
6 \\
7 \\
8 \\
9 \\
10 \\
11 \\
12 \\
13 \\
14 \\
15 \\
16 \\
17\end{array}$ & $\begin{array}{r}80 \\
71 \\
81 \\
100 \\
71 \\
80 \\
104 \\
82 \\
81 \\
100 \\
92 \\
68 \\
95 \\
79 \\
90 \\
95 \\
76\end{array}$ & $\begin{array}{l}67 \\
56 \\
65 \\
71 \\
61 \\
60 \\
83 \\
66 \\
69 \\
76 \\
71 \\
50 \\
61 \\
51 \\
60 \\
80 \\
50\end{array}$ & $\begin{array}{l}0 \cdot 83 \\
0 \cdot 78 \\
0 \cdot 80 \\
0 \cdot 71 \\
0 \cdot 86 \\
0 \cdot 75 \\
0 \cdot 87 \\
0 \cdot 81 \\
0 \cdot 85 \\
0 \cdot 76 \\
0 \cdot 78 \\
0 \cdot 72 \\
0 \cdot 64 \\
0 \cdot 64 \\
0 \cdot 66 \\
0 \cdot 84 \\
0 \cdot 60\end{array}$ & $\begin{array}{l}\text { Diabetes mellitus } \\
\text { Microcephaly } \\
\text { Pneumonia } \\
\text { Mental deficiency } \\
\text { Hysteria } \\
\text { Malnutrition } \\
\text { Mental deficiency } \\
\text { Pneumonia } \\
\text { Nephritis } \\
\text { Mental deficiency } \\
\text { Spastic diplegia } \\
\text { Tonsillitis } \\
\text { Spastic diplegia } \\
\text { Congenital lues } \\
\text { Hydrocephalus } \\
\text { Gastro-enteritis } \\
\text { Mental deficiency }\end{array}$ \\
\hline Average & & 64 & 0.76 & \\
\hline
\end{tabular}

There is a possible explanation of this apparent lack of correlation between the blood and cerebrospinal fluid sugar content. If changes in the blood sugar content are not immediately reflected in the cerebrospinal fluid sugar content, 
TABLE 3

THE RATIO OF CEREBROSPINAL FLUID SUGAR TO BLOOD SUGAR IN NORMAL CASES

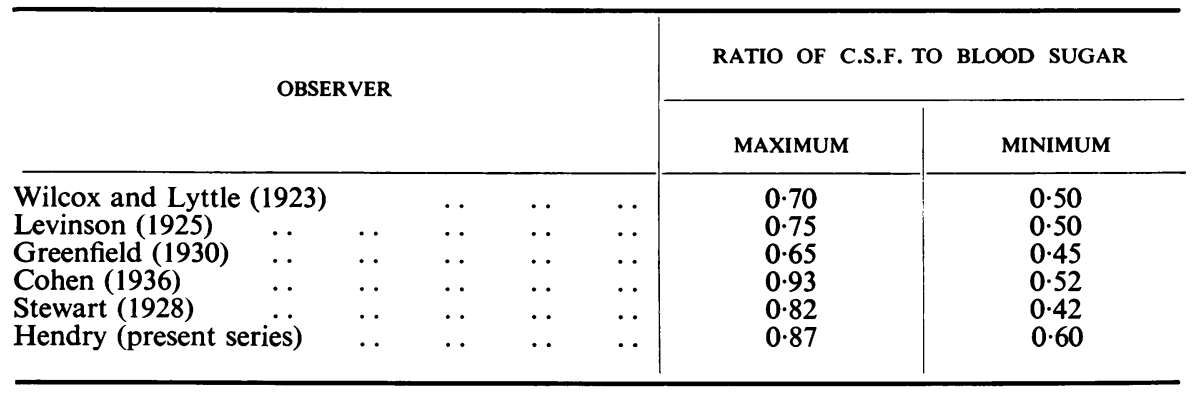

in other words if there is a lag in the transference of sugar from the blood to the cerebrospinal fluid, then, in the event of there being a sudden change in the blood sugar percentage, any correlation that may exist will not show itself until some time after this change takes place. To test this hypothesis an opportunity occurred to raise the blood sugar level rapidly by giving intravenous glucose and subsequently to examine the spinal fluid and the blood. It is known that when glucose is given intravenously there is a sudden rise in the blood sugar content up to about $300 \mathrm{mgm}$. per cent., followed by a rapid fall so that at the end of about one hour it has returned to approximately the normal level (Crawford, 1938). In table 4 the results of this experiment are shown. From this it will be seen that the ratio of fasting cerebrospinal

TABLE 4

BLOOD AND SPINAL FLUID SUGAR CONTENT AND RATIO OF CEREBROSPINAL FLUID TO BLOOD SUGAR IN FASTING STATE AND ONE AND A HALF HOURS AFTER 0.5 GM. GLUCOSE PER KILO. OF BODY WEIGHT GIVEN INTRAVENOUSLY

\begin{tabular}{|c|c|c|c|c|c|}
\hline \multicolumn{3}{|c|}{ FASTING STATE } & \multicolumn{3}{|c|}{$\begin{array}{l}1 \frac{1}{2} \text { HOURS AFTER } 35 \text { C.C. } 20 \text { PER CENT. } \\
\text { GLUCOSE INTRAVENOUSLY }\end{array}$} \\
\hline $\begin{array}{l}\text { BLOOD SUGAR } \\
\text { MGM. PER } \\
\text { CENT. }\end{array}$ & $\begin{array}{l}\text { C.S.F. SUGAR } \\
\text { MGM. PER } \\
\text { CENT. }\end{array}$ & $\begin{array}{c}\text { RATIO OF } \\
\text { C.S.F. TO } \\
\text { BLOOD SUGAR }\end{array}$ & $\begin{array}{l}\text { BLOOD SUGAR } \\
\text { MGM. PER } \\
\text { CENT. }\end{array}$ & $\begin{array}{l}\text { C.S.F. SUGAR } \\
\text { MGM. PER } \\
\text { CENT. }\end{array}$ & $\begin{array}{c}\text { RATIO OF } \\
\text { C.S.F. TO } \\
\text { BLOOD SUGAR }\end{array}$ \\
\hline 95 & 61 & 0.64 & 105 & 87 & $0 \cdot 82$ \\
\hline
\end{tabular}

fluid sugar to blood sugar was $0 \cdot 64$. An hour and a half after the intravenous injection of 35 c.c. of twenty per cent. glucose in saline the blood sugar was $105 \mathrm{mgm}$. per cent. and the cerebrospinal fluid sugar $86 \mathrm{mgm}$. per cent., giving a ratio of $0 \cdot 82$. From this experiment it seems probable that variations in the ratio of cerebrospinal fluid to blood sugar are dependent on variations in 
the blood sugar content and delay in their manifestation in the cerebrospinal fluid.

Tuberculous meningitis.-All investigators report a reduced spinal fluid sugar in tuberculous meningitis and the majority mention that this value varies with the stage of the disease. Neale and Esslemont (1928) quote several cases in which there was complete absence of sugar, a finding which is confirmed by Bokay (1929). Mogilnicki (1930), on the other hand, states that it is never completely absent and Soedjono's (1938) results support this. Nissen (1937) quotes $40 \mathrm{mgm}$. per cent. as the lower limit of normal cerebrospinal fluid sugar and finds that ninety-one per cent. of his tuberculous cases yield values below $30 \mathrm{mgm}$. per cent., whilst Tcherkassov and Jolkver (1935) find the majority (sixty-one per cent.) of their results under $20 \mathrm{mgm}$. per cent. These last three observers mention the finding of a raised blood sugar in the later stages of the disease. The findings from the literature are shown in table 5.

TABLE 5

THE CEREBROSPINAL FLUID SUGAR CONTENT IN TUBERCULOUS MENINGITIS

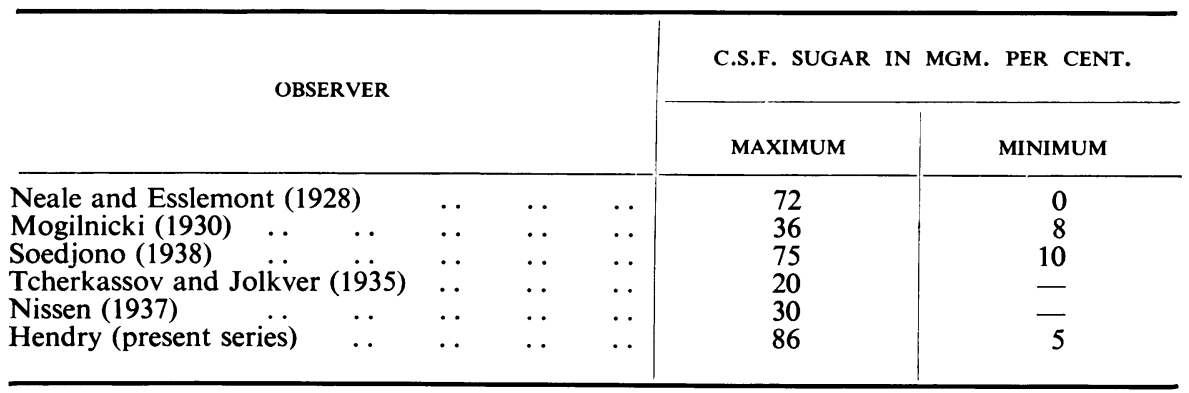

As regards the variations in cerebrospinal fluid sugar level during the course of the disease, Soedjono (1938) quotes four distinct phases : (a) when there is a gradual fall in cerebrospinal fluid sugar to 18 or $20 \mathrm{mgm}$. per cent. ; (b) a few days during which the value fluctuates between 10 and $40 \mathrm{mgm}$. per cent.; (c) a rise to normal limits of 50 to $65 \mathrm{mgm}$. per cent. ; and (d) a repetition of phase (b).

No blood sugar estimations are given for comparison. Weichsel and Herzger (1936) regard diminution in cerebrospinal fluid sugar as a diagnostic sign occurring twenty-five to thirty days before death. This decrease follows the rise in globulin and the increase in cell count. They find that about two weeks before death, there may be a slight increase in sugar content before the final drop to $10-20 \mathrm{mgm}$. per cent. and give the ultimate ratio of cerebrospinal fluid sugar to blood sugar as $0 \cdot 12-0 \cdot 08$.

Mogilnicki (1930) in reviewing seventy-two cases, attributes the finding of a high blood sugar content to the occurrence of convulsions. These, after a time lag, raise the cerebrospinal fluid sugar value, and, as will be seen later, such cases furnish a cerebrospinal fluid sugar well within normal limits and emphasize the necessity for withdrawing blood as nearly as possible at the same time as the cerebrospinal fluid in order to obviate misinterpretation of an unexpectedly high cerebrospinal fluid sugar content.

In the present investigation twenty-eight cases of tuberculous meningitis have been studied in children whose ages ranged from four months to eight and 
a half years. On an average, the blood and cerebrospinal fluid were examined every two or three days. In a few cases one estimation only was carried out, the children being in a late stage of the disease when admitted to hospital and dying before a second examination could be made. In the cases in which more than one estimation was possible the longest interval between the first and the last was twenty-two days and the shortest one day. This difference in time between first and final findings must be borne in mind, as, in the cases in which the interval is short, both estimations represent the condition in the late stage of the disease, whilst, in the cases in which there is a considerable interval, the first estimation represents the condition at an early stage and the last at a late stage. In table 6 the initiai and final blood sugar and cerebrospinal fluid sugar values are shown.

TABLE 6

THE CEREBROSPINAL FLUID AND BLOOD SUGAR IN TUBERCULOUS MENINGITIS

\begin{tabular}{|c|c|c|c|c|c|c|c|}
\hline \multirow{3}{*}{ NAME } & \multicolumn{3}{|c|}{ FIRST ESTIMATIONS } & \multirow{3}{*}{$\begin{array}{c}\text { TIME } \\
\text { INTERVAL } \\
\text { IN DAYS }\end{array}$} & \multicolumn{3}{|c|}{ FINAL ESTIMATIONS } \\
\hline & \multicolumn{2}{|c|}{$\begin{array}{c}\text { SUGAR IN MGM. } \\
\text { PER CENT. }\end{array}$} & \multirow{2}{*}{$\begin{array}{c}\text { RATIO OF } \\
\text { C.S.F. SUGAR TO } \\
\text { BLOOD SUGAR }\end{array}$} & & \multicolumn{2}{|c|}{$\begin{array}{l}\text { SUGAR IN MGM. } \\
\text { PER CENT. }\end{array}$} & \multirow{2}{*}{$\begin{array}{c}\text { RATIO OF } \\
\text { C.S.F. SUGAR TO } \\
\text { BLOOD SUGAR }\end{array}$} \\
\hline & BLOOD & C.S.F. & & & BLOOD & C.S.F. & \\
\hline 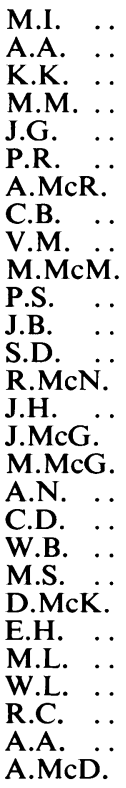 & $\begin{array}{r}\overline{77} \\
143 \\
105 \\
87 \\
74 \\
93 \\
50 \\
106 \\
88 \\
100 \\
75 \\
78 \\
274 \\
78 \\
123 \\
128 \\
75 \\
83 \\
76 \\
76 \\
120 \\
67 \\
91 \\
72 \\
68\end{array}$ & $\begin{array}{r}7 \\
14 \\
36 \\
27 \\
20 \\
22 \\
63 \\
12 \\
35 \\
24 \\
24 \\
18 \\
47 \\
86 \\
14 \\
36 \\
37 \\
15 \\
16 \\
27 \\
12 \\
19 \\
12 \\
58 \\
8 \\
13 \\
6 \\
21\end{array}$ & $\begin{array}{l}-\overline{0} \\
0 \cdot 18 \\
0 \cdot 25 \\
0 \cdot 24 \\
0 \cdot 23 \\
0 \cdot 27 \\
0 \cdot 67 \\
0 \cdot 24 \\
0 \cdot 32 \\
0 \cdot 27 \\
0 \cdot 23 \\
0 \cdot 21 \\
0 \cdot 60 \\
0 \cdot 31 \\
0 \cdot 18 \\
0 \cdot 29 \\
0 \cdot 28 \\
-7 \\
0 \cdot 21 \\
0 \cdot 32 \\
-7 \\
0 \cdot 24 \\
0 \cdot 16 \\
0 \cdot 47 \\
0 \cdot 12 \\
0 \cdot 14 \\
0 \cdot 08 \\
0 \cdot 30\end{array}$ & $\begin{array}{r}8 \\
- \\
3 \\
1 \\
- \\
1 \\
4 \\
2 \\
3 \\
4 \\
15 \\
14 \\
4 \\
3 \\
22 \\
13 \\
3 \\
6 \\
3 \\
4 \\
1 \\
2 \\
2 \\
5\end{array}$ & $\begin{array}{c}73 \\
- \\
84 \\
75 \\
- \\
\overline{89} \\
190 \\
175 \\
87 \\
63 \\
116 \\
85 \\
85 \\
70 \\
127 \\
83 \\
68 \\
83 \\
\frac{87}{2} \\
51 \\
83 \\
109 \\
108\end{array}$ & $\begin{array}{r}22 \\
- \\
32 \\
11 \\
- \\
20 \\
30 \\
34 \\
10 \\
14 \\
24 \\
16 \\
36 \\
13 \\
12 \\
17 \\
11 \\
14 \\
5 \\
8 \\
11 \\
6 \\
15 \\
20\end{array}$ & $\begin{array}{l}0 \cdot 30 \\
- \\
0 \cdot 38 \\
0 \cdot 14 \\
\overline{-} \\
0 \cdot 22 \\
0 \cdot 16 \\
0 \cdot 13 \\
0 \cdot 11 \\
0 \cdot 22 \\
0 \cdot 20 \\
0 \cdot 18 \\
0 \cdot 42 \\
0 \cdot 17 \\
0 \cdot 08 \\
\overline{0 \cdot 13} \\
0 \cdot 20 \\
0 \cdot 06 \\
\overline{0.09} \\
\overline{0.21} \\
0.07 \\
0 \cdot 14 \\
0 \cdot 18\end{array}$ \\
\hline
\end{tabular}

Taking a sugar concentration in the cerebrospinal fluid of $50 \mathrm{mgm}$. per cent. as the lower limit of normality, twenty-five of the twenty-eight cases showed 
initial values below normal, and taking 0.60 as the lower limit of the ratio of cerebrospinal fluid sugar to blood sugar, twenty-three of the cases showed a ratio below this figure at the first examination. In twenty-two of the cases the blood and cerebrospinal fluid sugar was estimated more than once, and in the final examinations of these, which were in each case made within one or two days of death, all gave a cerebrospinal fluid sugar concentration of less than $50 \mathrm{mgm}$. per cent. and a ratio of cerebrospinal fluid sugar to blood sugar of between 0.06 and 0.42 . In fourteen of these cases the ratio of cerebrospinal fluid sugar to blood sugar had fallen between the first and last estimations. Fig. 1 illustrates the progressive fall in the cerebrospinal fluid sugar content

\section{Fic 1}
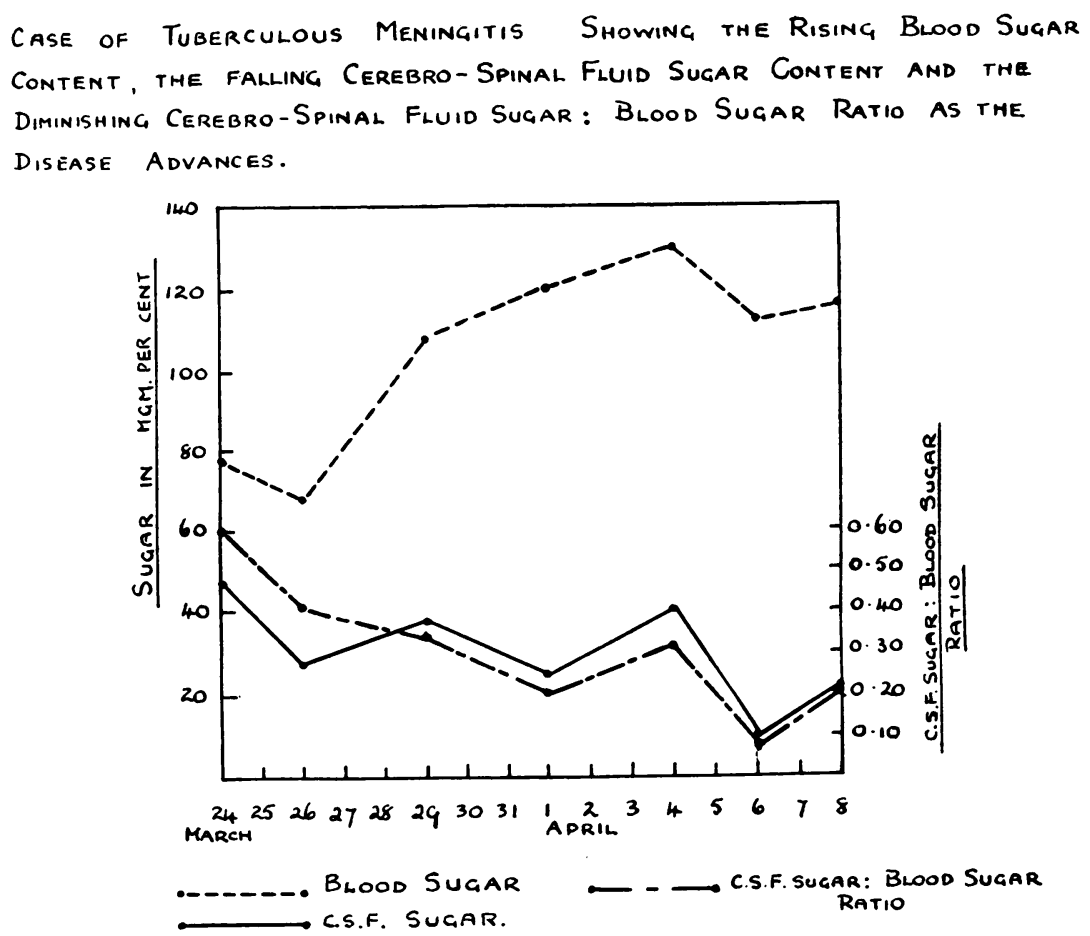

and the diminishing ratio of cerebrospinal fluid sugar to blood sugar in a typical case. Of the three cases which showed a normal cerebrospinal fluid sugar value two gave a ratio of cerebrospinal fluid sugar to blood sugar of less than $0 \cdot 60$, suggesting that the relatively high sugar content of the cerebrospinal fluid was due to disturbance in the blood sugar concentration.

This is well exemplified in the case of R.McN., a child aged two and a half years who, on admission to hospital, did not show signs typical of meningitis. $\mathrm{He}$ had been having continuous convulsions for one and a half hours before admission and a lumbar puncture was performed half an hour later. The 
cerebrospinal fluid sugar was $86 \mathrm{mgm}$. per cent., a figure well above the normal value and, as an isolated observation, a strong point against the case being one of meningitis, but the blood taken at the same time gave a sugar concentration of $274 \mathrm{mgm}$. per cent. and the ratio of cerebrospinal fluid sugar to blood sugar was 0.31 . In this case, hyperglycaemia induced by the convulsions had led to a marked and misleading increase in the concentration of sugar in the cerebrospinal fluid, but in spite of this, the ratio of cerebrospinal fluid sugar to blood sugar lay well below the normal limit.

Of the two cases which gave a ratio of 0.60 or over, one with a ratio of 0.67 died before a second estimation could be made, but the other, with an initial ratio of 0.60 showed a ratio of 0.41 on the second examination and of 0.20 fifteen days subsequent to the first examination. The results from this case are shown in fig. 1 .

In the majority of cases a cerebrospinal fluid sugar concentration below $50 \mathrm{mgm}$. per cent. is strong presumptive evidence of meningitis, but a high finding must be viewed with caution unless a concomitant blood sugar estimation is carried out, for variations in this have an influence on the cerebrospinal fluid sugar content. The ratio of cerebrospinal fluid sugar to blood sugar is always below normal and is therefore of greater diagnostic value.

Purulent meningitis.-Most workers are agreed that in the early stage of purulent meningitis, the cerebrospinal fluid sugar is in small amount or completely absent.

Levinson and Cohn (1936) reporting five cases of meningococcal meningitis, examined before injection of serum, found cerebrospinal fluid sugar values ranging from zero to a maximum of $23 \mathrm{mgm}$. per cent. with an average of $9 \mathrm{mgm}$. per cent. Three cases of influenzal and five of streptococcal meningitis showed absence of sugar. Ford (1937) mentions a cerebrospinal fluid sugar of $10 \mathrm{mgm}$. per cent. or less. Neale and Esslemont (1928) find an initial low reading with some fluctuations from day to day until recovery when the cerebrospinal fluid sugar rises to the normal level. In two fatal cases it disappeared entirely. Soedjono (1938) remarks on a constant fall in the cerebrospinal fluid sugar in purulent meningitis and a low content which is most marked shortly before death.

Fourteen cases of meningococcal meningitis have been studied, and the blood and spinal fluid sugar levels found on admission are set out in table 7 . None of the cases received serum ; all were treated with prontosil. From this it will be seen that the cerebrospinal fluid sugar concentration ranged, on admission, from 0-52 mgm. per cent., with an average of $15 \mathrm{mgm}$. per cent. The ratio of cerebrospinal fluid sugar to blood sugar varied from 0.08-0.48 with an average of $0 \cdot 19$. If recovery took place, the sugar content slowly increased and after a varying period, usually less than a week, ran its normal parallel course to the blood sugar. The latter is usually raised in the first stage of the disease as at this time convulsions commonly occur. Fig. 2 illustrates a typical case in which recovery took place. One case of pneumococcal, two of B. coli and two of influenzal meningitis were also investigated. The children were all critically ill and died soon after admission. The sugar content of the cerebrospinal fluid was reduced to zero in every case. 
TABLE 7

THE BLOOD AND CEREBROSPINAL FLUID SUGAR AND CHLORIDE CONTENT DURING THE ACUTE STAGE OF MENINGOCOCCAL MENINGITIS

\begin{tabular}{|c|c|c|c|c|c|c|}
\hline NAME & $\begin{array}{c}\text { BLOOD SUGAR } \\
\text { MGM. } \\
\text { PER CENT. }\end{array}$ & $\begin{array}{c}\text { C.S.F. SUGAR } \\
\text { MGM. } \\
\text { PER CENT. }\end{array}$ & $\begin{array}{l}\text { RATIO OF } \\
\text { C.S.F. SUGAR } \\
\text { TO BLOOD } \\
\text { SUGAR }\end{array}$ & $\begin{array}{c}\text { BLOOD } \\
\text { NaCl } \\
\text { MGM. } \\
\text { PER CENT. }\end{array}$ & $\begin{array}{c}\text { C.S.F. } \\
\text { NaCl } \\
\text { MGM. } \\
\text { PER CENT. }\end{array}$ & $\begin{array}{c}\text { RATIO OF } \\
\text { C.S.F. NaCl } \\
\text { TO BLOOD } \\
\text { NaCl }\end{array}$ \\
\hline 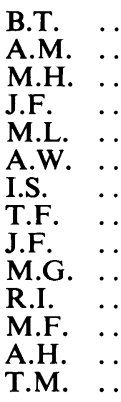 & $\begin{array}{r}84 \\
91 \\
80 \\
63 \\
111 \\
53 \\
113 \\
69 \\
65 \\
125 \\
91 \\
65\end{array}$ & $\begin{array}{c}35 \\
10 \\
\text { Absent } \\
10 \\
12 \\
52 \\
12 \\
17 \\
10 \\
\text { Less than } 5 \\
\text { Less than } 5 \\
5 \\
44 \\
\text { Less than } 5\end{array}$ & $\begin{array}{l}0.41 \\
- \\
0.12 \\
0.19 \\
0.46 \\
\overline{-} \\
0.32 \\
0.08 \\
0.08 \\
0.08 \\
0.04 \\
0.48 \\
0.08\end{array}$ & $\begin{array}{l}465 \\
379 \\
363 \\
414 \\
517 \\
413 \\
\overline{445} \\
476 \\
427 \\
338 \\
395 \\
366 \\
498\end{array}$ & $\begin{array}{l}716 \\
616 \\
640 \\
616 \\
643 \\
610 \\
646 \\
635 \\
648 \\
585 \\
623 \\
640 \\
630 \\
630\end{array}$ & $\begin{array}{l}1 \cdot 54 \\
1 \cdot 62 \\
1 \cdot 49 \\
1 \cdot 48 \\
1 \cdot 24 \\
1 \cdot 47 \\
1 \cdot 42 \\
1 \cdot 36 \\
1 \cdot 36 \\
1 \cdot 83 \\
1 \cdot 64 \\
1 \cdot 72 \\
1 \cdot 28\end{array}$ \\
\hline
\end{tabular}

FIC 2.

Case of Meningococcal Meningitis Showing the fahl in the Blood Sugar Content and the Rise in the cerebro Spinal fluid Sugar content as Recovery TAIKES Place

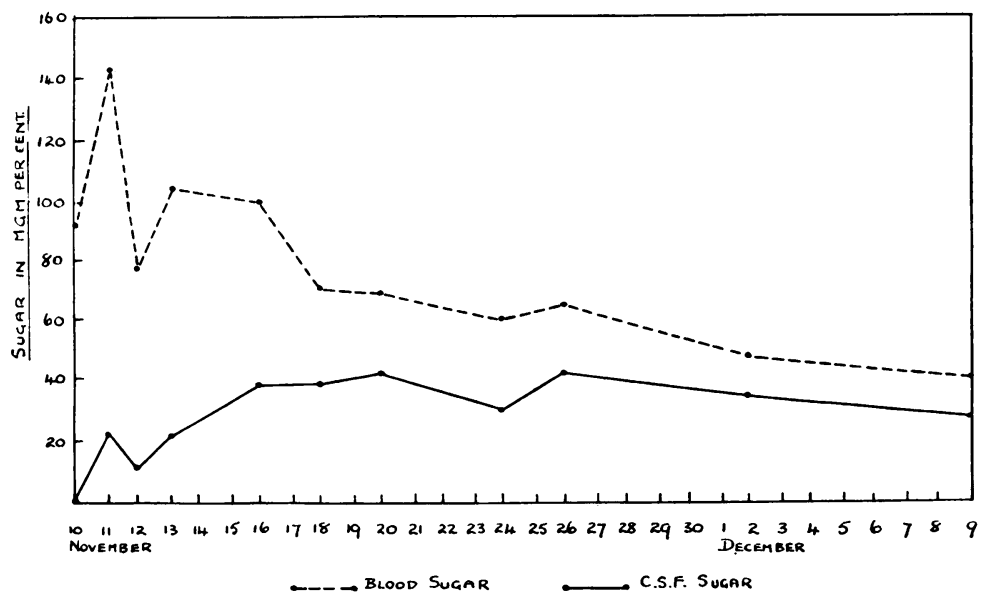

As a demonstration of the value of estimating the cerebrospinal fluid sugar and, in particular, the ratio it bears to the blood sugar for differential diagnosis, the following cases may be mentioned.

Case 1.-J.H. was a case of abdominal tuberculosis. On account of persistent nuchal rigidity in addition to the other clinical findings, he was lumbar punctured five times between the onset of the stiffness of the neck and death nine days later. The blood and cerebrospinal fluid findings are shown in table 8. From this it will be seen, that with the exception of the results on 
May 22, 1938, the cerebrospinal fluid sugar content and percentage ratio were within normal limits. No meningitis was found on post-mortem examination.

TABLE 8

BLOOD AND CEREBROSPINAL FLUID SUGAR CONTENT IN A CASE OF ABDOMINAL TUBERCULOSIS SUSPECTED OF HAVING MENINGITIS

\begin{tabular}{c|c|c|c}
\hline DATE & $\begin{array}{c}\text { BLOOD SUGAR } \\
\text { MGM. PER CENT. }\end{array}$ & $\begin{array}{c}\text { CEREBROSPINAL } \\
\text { FLUID SUGAR } \\
\text { MGM. PER CENT. }\end{array}$ & $\begin{array}{c}\text { RATIO OF C.S.F. } \\
\text { SUGAR TO BLOOD } \\
\text { SUGAR }\end{array}$ \\
\hline 16.5 .38 & 92 & 70 & $0 \cdot 75$ \\
19.5 .38 & 78 & 66 & $0 \cdot 84$ \\
20.5 .38 & 112 & 98 & $0 \cdot 87$ \\
22.5 .38 & 93 & 28 & $0 \cdot 30$ \\
25.5 .38 & 64 & 66 & $1 \cdot 03$ \\
\hline
\end{tabular}

Case 2.-I.K. had hilum tuberculosis, and a history of vomiting, constipation, anorexia and listlessness raised the suspicion of meningitis. The cerebrospinal fluid sugar was $71 \mathrm{mgm}$. per cent., and the ratio of cerebrospinal fluid to blood sugar $0 \cdot 90$.

Case 3.-J.R. was a case of benign lymphocytic meningitis. Table 9 shows the blood and cerebrospinal fluid findings. In this case the diagnosis on admission was doubtful on clinical findings alone but the cerebrospinal fluid sugar content and the percentage ratio afforded strong evidence against its being a case of true meningitis.

TABLE 9

BLOOD AND CEREBROSPINAL FLUID SUGAR CONTENT IN A CASE OF BENIGN LYMPHOCYTIC MENINGITIS

\begin{tabular}{|c|c|c|c|c|}
\hline DATE & $\begin{array}{l}\text { BLOOD SUGAR } \\
\text { MGM. PER CENT. }\end{array}$ & $\begin{array}{l}\text { CEREBROSPINAL } \\
\text { FLUID SUGAR } \\
\text { MGM. PER CENT. }\end{array}$ & $\begin{array}{l}\text { RATIO OF C.S.F. } \\
\text { SUGAR TO } \\
\text { BLOOD SUGAR }\end{array}$ & CELLS \\
\hline $\begin{array}{r}27.6 .38 \\
28.6 .38 \\
2.7 .38 \\
11.7 .38 \\
14.7 .38\end{array}$ & $\frac{128}{-}$ & $\begin{array}{l}85 \\
81 \\
66 \\
54 \\
51\end{array}$ & $\begin{array}{l}0.66 \\
\bar{Z} \\
0.69\end{array}$ & $\begin{array}{l}\text { Lymphocytes } \\
\text { Lymphocytes } \\
\text { Lymphocytes } \\
\text { Lymphocytes } \\
\text { Lymphocytes }\end{array}$ \\
\hline
\end{tabular}

Two cases of anterior poliomyelitis were also examined. The results of sugar estimations on blood and spinal fluid are set out in table 10. In these two cases, as in case 3, the cerebrospinal fluid sugar content and the ratio of cerebrospinal fluid sugar to blood sugar were not reduced below the normal limits.

TABLE 10

BLOOD AND CEREBROSPINAL FLUID SUGAR CONTENT IN TWO CASES OF POLIOMYELITIS

\begin{tabular}{c|c|c|c}
\hline \multirow{2}{*}{ CASE } & $\begin{array}{c}\text { BLOOD SUGAR } \\
\text { MGM. PER CENT. }\end{array}$ & $\begin{array}{c}\text { C.S.F. SUGAR } \\
\text { MGM. PER CENT. }\end{array}$ & $\begin{array}{c}\text { RATIO OF C.S.F. SUGAR } \\
\text { TO BLOOD SUGAR }\end{array}$ \\
\hline 1 & 54 & 50 & $0 \cdot 92$ \\
2 & 153 & 137 & $0 \cdot 96$ \\
\hline
\end{tabular}




\section{Percentage of chlorides in blood and cerebrospinal fluid}

Normal cases.-Most workers are agreed that, in adults, the normal chloride content of the blood varies between 450 and $600 \mathrm{mgm}$. per cent., and of the cerebrospinal fluid between 700 and $750 \mathrm{mgm}$. per cent. and that as a rule the results for children are similar, though Stewart (1928) gives 636-763 mgm. per cent. as the range for the cerebrospinal fluid chloride in the latter cases. Table 11 gives a few of the results of other workers. This shows that the normal blood chloride lies between 450-660 mgm. per cent. and cerebrospinal fluid chloride between 636-783 mgm. per cent.

TABLE 11

THE NORMAL VALUES FOR BLOOD AND CEREBROSPINAL FLUID CHLORIDE

\begin{tabular}{|c|c|c|c|c|c|}
\hline \multicolumn{4}{|l|}{ OBSERVER } & \multirow{2}{*}{$\begin{array}{c}\text { BLOOD NaCl } \\
\text { MGM. PER CENT. } \\
450-500 \\
500-600 \\
475-550 \\
- \\
35 \overline{-}\end{array}$} & \multirow{2}{*}{$\begin{array}{c}\text { C.S.F. NaCl } \\
\text { MGM. PER CENT. } \\
- \\
720-740 \\
700-750 \\
636-763 \\
696-783 \\
635-770\end{array}$} \\
\hline $\begin{array}{l}\text { Hawk and Bergein (1938) } \\
\text { Finkelstein and Merson (1934) } \\
\text { Soedjono (1938) } \\
\text { Stewart (children) (1928) } \\
\text { Neale and Esslemont (1928) } \\
\begin{array}{l}\text { Hendry (children) } \\
\text { (present series) }\end{array}\end{array}$ & $\begin{array}{l}\cdots \\
\ldots \\
\ldots\end{array}$ & $\begin{array}{l}\cdots \\
\cdots \\
\cdots \\
\cdots \\
\cdots\end{array}$ & $\begin{array}{l}\cdots \\
\cdots \\
\cdots \\
\cdots \\
\cdots\end{array}$ & & \\
\hline
\end{tabular}

In the present investigation cerebrospinal fluid chloride and blood chloride were estimated in forty children who had no sign of meningeal involvement. The blood chloride was found to range from $355-543 \mathrm{mgm}$. per cent. and the cerebrospinal fluid chloride from 635-770 mgm. per cent. The low readings can be explained by the fact that many of these cases were dehydrated infants and children admitted with a history of vomiting, diarrhoea and convulsions and were lumbar punctured for diagnostic purposes. In every case in which the blood chloride was low, a lowered reading was also found in the cerebrospinal fluid. These results correspond with the findings of Finkelstein and Merson (1934), Linder and Carmichael (1928) and Nowika (1924) who hold that blood and spinal fluid chloride run a parallel course. In order to prove this from the present series, the ratio of cerebrospinal fluid chloride to the blood chloride was calculated in each case. This was found to range from 1.321.91 with a ratio of $1 \cdot 60-1.65$ in a third of the cases and the average at 1.59. As most of these cases were lumbar punctured once only, no serial figures are available.

Tuberculous meningitis.-Investigation of the literature on the chloride content of cerebrospinal fluid in tuberculous meningitis shows that most workers look on $500-690 \mathrm{mgm}$. per cent. as the expected range. All agree that there is a progressive diminution with the progress of the disease.

Nowika (1924), Linder and Carmichael (1928) and Fowweather (1930) believe that the low cerebrospinal fluid chlorides indicate a general reduction in body chlorides. Neale and Esslemont (1928) mention a general agreement 
between the relative blood and cerebrospinal fluid chloride content but do not establish any strict ratio for meningitic or non-meningitic cases. Nissen (1937) finds that the values for cerebrospinal fluid chlorides and sugar tend to run parallel. From table 12 it appears that cerebrospinal fluid chloride in tuberculous meningitis may lie between 450 and $680 \mathrm{mgm}$. per cent.

TABLE 12

THE CEREBROSPINAL FLUID CHLORIDE CONTENT IN TUBERCULOUS MENINGITIS

\begin{tabular}{|c|c|c|c|c|c|}
\hline \multicolumn{4}{|l|}{ OBSERVER } & \multicolumn{2}{|c|}{ C.S.F. NaCl IN MGM. PER CENT. } \\
\hline & & & & MAXIMUM & MINIMUM \\
\hline $\begin{array}{l}\text { Soedjono (1938) } \\
\text { Fowweather }(1930) \ldots \\
\text { Finkelstein and Merson (1934) } \\
\text { Neale and Esslemont (1928) } \\
\text { Hendry (present series) }\end{array}$ & $\begin{array}{l}\cdots \\
\cdots \\
\cdots \\
\cdots\end{array}$ & $\begin{array}{l}\cdots \\
\cdots \\
\cdots \\
\cdots\end{array}$ & $\begin{array}{l}\cdots \\
\cdots \\
\cdots \\
\cdots \\
\cdots\end{array}$ & $\begin{array}{l}600 \\
640 \\
680 \\
673 \\
757\end{array}$ & $\begin{array}{l}450 \\
590 \\
500 \\
543\end{array}$ \\
\hline
\end{tabular}

The present series comprises twenty-eight cases. In many of these the spinal fluid chloride was estimated on several occasions, but in table 13 only the first and last estimations are shown. From this it will be seen that on the first examination the chloride ranged between 689 and $549 \mathrm{mgm}$. per cent. and shortly before death between 757 and $561 \mathrm{mgm}$. per cent. The average ratio of cerebrospinal fluid chloride to blood chloride both in the early and in the late stage was $1 \cdot 55$. These identical average ratios, which correspond so closely to the average normal ratio of 1.59 , strongly suggest that any reduction in the cerebrospinal fluid chloride content in tuberculous meningitis is not due to the meningeal condition, but to reduction of chloride in the blood. The fact that there is also reduction in the urinary chlorides strengthens this supposition. Reference to fig. 3 shows the course of blood and spinal fluid chloride and sugar content from a typical case and demonstrates the parallelism of the chloride throughout the disease in contrast to the ever increasing difference in the two sugar curves. Referring to the tables (6 and 13) showing the results of sugar and chloride estimations in blood and cerebrospinal fluid on admission and shortly before death, it will be noticed that, at the onset, a low cerebrospinal fluid sugar content and ratio is a much more constant finding than a lowered chloride content and a more satisfactory test from a diagnostic point of view.

Meningococcal meningitis.-In meningococcal meningitis, the chlorides are of little diagnostic value although prognostically their rise indicates the likelihood of recovery. Most workers find the cerebrospinal fluid chloride content diminished on admission, but to a lesser extent than in tuberculous meningitis. In the present series, the cerebrospinal fluid chloride on admission ranged from 716-585 mgm. per cent., the blood chloride from 498-338 mgm. per cent. and the ratio from 1.83-1.24 with an average of 1.41 . This last value, as in tuberculous meningitis, approximates to the normal. Most cases showed-a gradual rise in cerebrospinal fluid chloride content with clinical improvement, 
Other types.-Two cases of B. coli, two of influenzal and one of pneumococcal meningitis showed a similar reduction to that found in meningococcal meningitis.

\section{Conclusions}

1. In the normal subject variations in the cerebrospinal fluid sugar content are dependent on variations in the blood sugar level, but changes in the latter are not immediately reflected in the cerebrospinal fluid. 
Fic 3

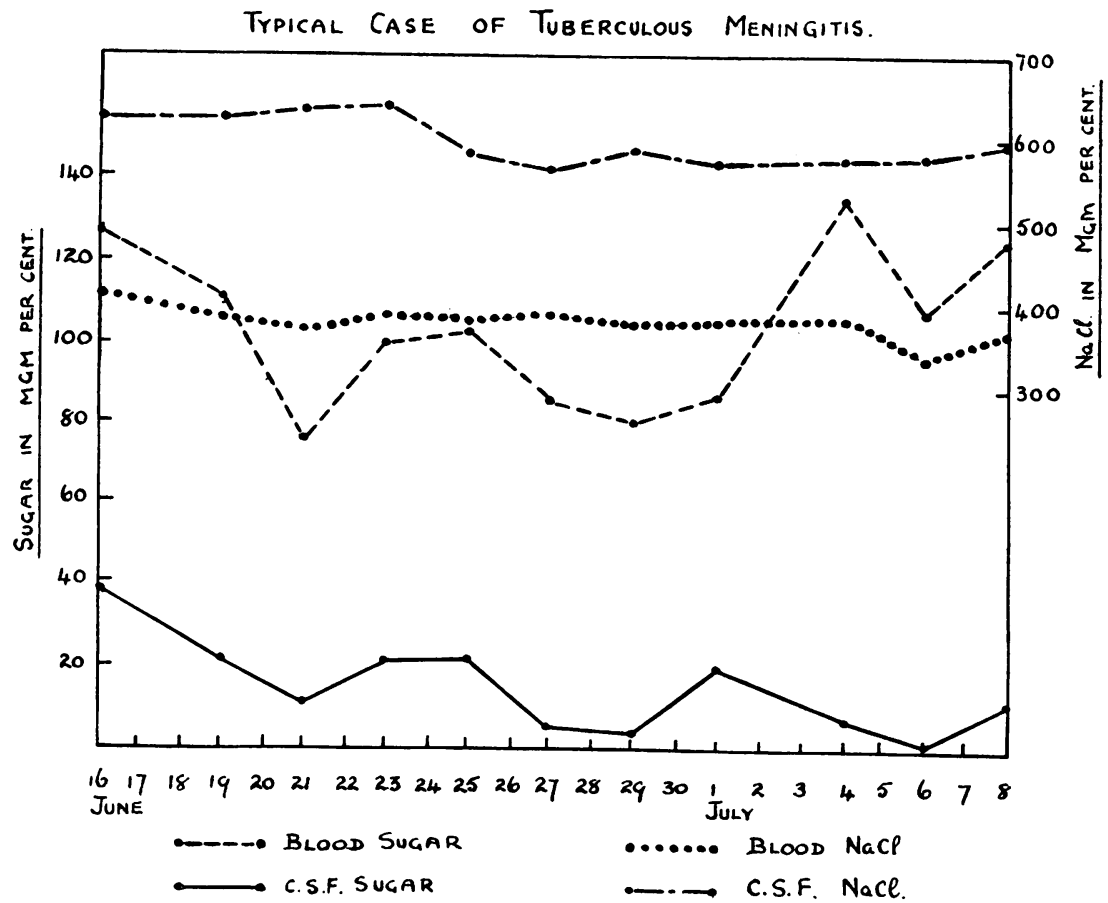

FIC. 4

Typical Case of Meningococcal Meningitis Showing the

Parallel Course of the Blood and Cerebro-Sanal fluid Chlorides and the Return to Normal level of the Cerebro-Spinal fluid Sugar

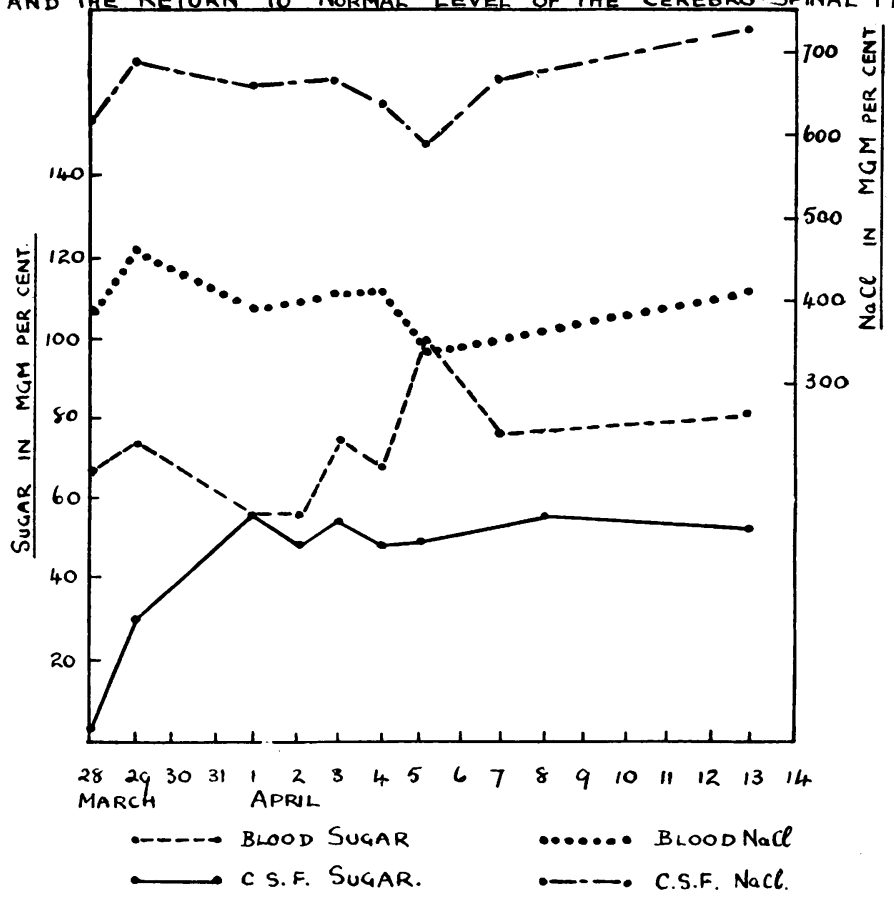

$\mathrm{N}^{*}$ 
2. The lower limit for cerebrospinal fluid sugar content in normal cases is $50 \mathrm{mgm}$. per cent. and the ratio of cerebrospinal fluid sugar to blood sugar 0.6.

3. In tuberculous meningitis, the cerebrospinal fluid sugar content is reduced as is also the ratio of cerebrospinal fluid sugar to blood sugar; the reduction in both becomes more marked as the disease progresses. If convulsions occur, the cerebrospinal fluid sugar level may be raised to apparently normal limits, but the blood sugar is also raised and the ratio of cerebrospinal fluid sugar to blood sugar remains below normal.

4. In meningococcal meningitis, the cerebrospinal fluid sugar is reduced and may be almost entirely absent and the ratio of cerebrospinal fluid sugar to blood sugar is below normal. As recovery takes place, the cerebrospinal fluid sugar content and the ratio of cerebrospinal fluid sugar to blood sugar return to normal.

5. The cerebrospinal fluid chloride content is reduced in all forms of meningitis but this is due to a reduction in the blood chloride content.

6. Chloride reduction in the early stages of tuberculous meningitis is less constant than reduction in the cerebrospinal fluid sugar content.

Thanks are due to Professor G. B. Fleming and to other members of the clinical and biochemical staff of the hospital for valuable help. This work was carried out during the tenure of a Muirhead Scholarship and part of the expenses were defrayed by the Medical Research Council.

\section{REFERENCES}

Bokay, Z. (1929). Orv. Hetil., 73, 467.

Cohen, H. (1936). Quart. J. Med., 5, 159.

Cohn, D. J., Levinson, A., and McCarthy, F. (1933). Amer. J. Physiol., 103, 613.

Crawford, T. (1938). Arch. Dis. Childh., 13, 69.

Finkelstein, L. O., and Merson, F. S. (1934). Rev. franç. Pédiat, 10, 204.

Folin, O., and Wu, H. (1920). J. biol. Chem., 41, 367.

Ford, F. R. (1937). Diseases of the Nervous System in Infancy, Childhood and Adolescence, London.

Fowweather, F. S. (1930). Arch. Dis. Childh., 5, 80.

Goodwin, G., and Shelley, H. J. (1925). Arch. intern. Med., 35, 242.

Greenfield, J. G. (1930). Clinical Interpretation of Aids to Diagnosis, London.

Hawk, P. B., and Bergein, O. (1938). Practical Physiological Chemistry, London.

Levinson, A. (1925). Amer. J. Dis. Child., 30, 774.

- and Cohn, D. J. (1936). Ibid., 51, 17.

Linder, G. C., and Carmichael, E. A. (1928). Biochem. J., 22, 46.

MacLean, M. B. (1936). Arch. Dis. Childh., 9, 247.

Mogilnicki, T. (1930). Acta Paediatr., Stockh., 11, 369.

Neale, A. N., and Esslemont, M. S. (1928). Arch. Dis. Childh., 3, 243.

Nissen, N. I. (1937). Acta Psychiat., 12, 173.

Nowika, H. (1924). Arch. Méd. Enf., 28, 726.

Rimele, B. (1938). Arch. Kinderheilk., 113, 223.

Soedjono, D. P. (1938). Maandschr. Kindergeneesk., 7, 337.

Stewart, D. (1928). Arch. Dis. Childh., 3, 96.

Tcherkassov, A. V., and Jolkver, E. E. (1935). Rev. franç. Pédiat, 11, 350.

Van Slyke, D.D. (1924). J. biol. Chem., 58, 523.

Weichsel, M., and Herzger, G. (1936). J. Pediat., 9, 763.

Wilcox, H. B., and Lyttle, J. D. (1923). Arch. Pediat., 140, 215.

Wright, S., Herr, E. S., and Paul, J. R. (1931). J. clin. Invest., 9, 443. 